\title{
改良統計的グリーン関数法に基づく 1923 年関東地震の強震動生成域と強震動の推定 ESTIMATION OF STRONG MOTION GENERATION AREAS AND STRONG MOTIONS DURING THE 1923 KANTO EARTHQUAKE USING REVISED STOCHASTIC GREEN'S FUNCTION METHOD
}

\author{
佐 藤 智 美* \\ Toshimi SATOH
}

\begin{abstract}
We estimate strong motion generation areas and strong motions during the 1923 Kanto earthquake by the forward modeling of the seismic intensity scale using the revised stochastic Green's function method. The nonlinear site effects on the seismic intensity scale are considered. The strong motion generation areas are located at almost the same position as large slip areas. Site amplification factors of spectral model and site coefficients of envelope model are interpolated by applying the Kriging method. Strong motions are spatially estimated using this method. The strong motion estimated at Hongo is consistent with the restored Imamura-type seismogram.
\end{abstract}
Keywords : The 1923 Kanto earthquake, Seismic Intensity scale, Nonlinear site response, Strong motion generation area, Stochastic Green's function method, Kriging 1923 年関東地震, 震度, 非線形地盤応答, 強震動生成域, 統計的グリーン関数法, クリギング

\section{1. はじめに}

首都圏の超高層建物等に対する設計用地震動や、 $\mathrm{BCP}$ 、防災対策 を考える上で、1923 年関東地震 $\left(M_{\mathrm{J}} 7.9\right)$ の強震動は無視できない。こ れまで、この地震の震度分布を再現する震源モデルの推定や強震動 の再現・予測や震度推定等が行われている例えば、1) 7)。しかし、従来 の統計的グリーン法は、実体波のみを考慮しているため、関東平野 の厚い堆積層の影響を受けて卓越する表面波を考慮できない。また、 長周期を三次元有限差分法で推定するハイブリッド法では、地下構 造モデルの周期 2〜3 秒以下での精度の問題などから、接続周期が 2 〜3 秒程度である。したがって、首都圈の半数の超高層建物の固有 周期である 1.5 2.5 秒 8)程度のやや長周期地震動や、中・低層の建 物の被害に影響が大きい周期 1 2 秒程度の波 9 ) は、主に統計的グリ ーン関数法や経験的グリーン関数法で計算される。経験的グリーン 関数法を適用するには、中規模地震が震源域にほとんどない10)ため、 大きな距離補正が必要となる。この場合、表面波の距離補正を実体 波と同じとする仮定や、継続時間や経時特性が距離補正されない影 響や、メカニズム解の違いの影響が生じる。

このような問題を解決するため、筆者は、フィリピン海プレート の中規模地震記録に基づき、表面波と散乱波を考慮した改良統計的

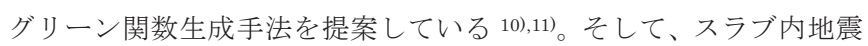
の記録に基づく改良統計的グリーン関数生成手法 ${ }^{11)} 1987$ 年千葉 県東方沖地震 $(M \mathrm{~s} 6.7)$ の強震動予測に適用し、観測波形の再現を通じ て改良統計的グリーン法の妥当性を検証した ${ }^{12)}$ 。本研究では、プレ 一ト境界地震の記録に基づく改良統計的グリーン関数法 10),122によ り、震度分布を再現する 1923 年関東地震の強震動生成域と背景領
域から成る震源モデルの推定とこれを用いた強震動推定を行う。 具体的には、はじめに、強震動生成域の震源パラメータを設定し、 改良統計的グリーン関数法 10),12)により、経験的地盤増幅率、経時特 性の経験的サイト特性が得られている強震観測点 10)で、地盤が線形 時の地表での波形を推定する。次に、この波形から算出される計測 震度から、地盤が線形時と非線形時の計測震度の関係式 13)を用いて、 非線形時の計測震度を算出する。そして、この計測震度が震度分布 を最も良く再現する震源パラメータを選択する、フォワードモデリ ングを行う。地表での地盤が線形時の強震動波形が推定されるため、 工学的基盤や、地盤の非線形性を考慮した地表での強震動波形は、 地点固有の地盤情報に応じて個別に推定する。

しかし、改良統計的グリーン関数 10)には、経験的地盤増幅率、経 時特性の経験的サイト特性が用いられているため、強震観測点での み予測が可能であった。面的に強震動波形を推定するため、本研究 では、経験的地盤増幅率・サイト係数のモデル化を行なった。はじ めに、 $T z$ 平行成層地盤モデルの地震基盤から工学的基盤までの 1 次固有周期の 1/4) 14) とVS30 を用いて経験式(回帰式)を作成する。 次に、経験式からの残差に、クリギング手法例えば、15),16)を導入して 面的補間を行う。これにより、経験式(回帰式)のみでは、サイト特 性が平均より大きいサイトでは過少評価、小さいサイトでは過大評 価となる問題が解決できる。また、観測点の近傍のサイトでは、観 測点と類似の経験的地盤増幅率・サイト係数を評価することができ ある。そして、面的補間法と推定された震源モデルを用いて面的強 震動の推定例を示し、今村式 2 倍強震計記録の復元波形 17$)$ が得られ ている本郷での推定強震動波形と復元波形との比較・考察を行う。 


\section{2. 手法}

（1）強震動生成域と強震観測点での強震動の推定手法

1923 年関東地震 $(M \mathrm{~J} 7.9)$ の視的断層面としては、Sato et al. $\left.{ }^{18}\right)$ の $130 \mathrm{~km} \times 70 \mathrm{~km}$ の矩形平面断層を、地震調査研究推進本部 19)のフ イリピン海プレートの形状に基づき、 $5 \mathrm{~km} \times 5 \mathrm{~km}$ の正方形の要素断 層からなる曲面断層に置き換えたものを用いる。フィリピン海プレ 一トの深さが浅いことが考慮されており 19)、このプレート上端より $1 \mathrm{~km}$ 浅い位置に要素断層を配置した ${ }^{19)}$ 。要素断層の走向、傾斜角も、 プレートの形状に合わせて設定した。地震モーメント $\left(1 \times 10^{21} \mathrm{Nm}\right)$ 、 破壊開始点の緯度・経度は、Sato et al. 18)を用いた。震源の $\mathrm{S}$ 波速 度、密度も Sato et al. ${ }^{18)}$ の平均的值の $3.5 \mathrm{~km} / \mathrm{s} 、 2.7 \mathrm{~g} / \mathrm{cm}^{3}$ とした。 Fig. 1 に、断層と、用いる強震観測点(K-NET、KiK-net、気象庁 95 型震度計)の位置を示す。図中には、気象庁の震度階級も示している。 なお、当時は震度 7 の階級は設定されていない。

そして、強震動生成域と背景領域からなる震源モデルを設定し、 改良統計的グリーン関数法 10),12)で、地盤が線形時の地表での地震動 を推定する。強震動生成域は 2 個と仮定し、強震動生成域との長さ、 幅、位置と、 2 つの応力降下量の比を推定震源パラメータとする。 強震動生成域に関寸る他のパラメータは、強震動予測レシピ 20)に基 づき、Boatwrightt"1)の式と、全体のすべり量が断層全体のすべり量 の 2 倍という関係から算出する 20)。背景領域は、強震動予測レシピ 20)に従って算出する。次に、地盤が線形時と非線形時の震度の関係 式 13)に基づき、地盤が非線形時の震度を算出し、これが震度分布に 最も合う震源パラメータを選択する。震度分布に合う広帯域震源モ デルを推定する際に、震度に対する地盤の非線形性を考慮する点も 従来と異なる特徴である。震度分布としては、木造住家被害データ に基づく諸井・武村 22)を主に用いた。ただし、報告なし(震度 5 弱 以下)の領域は、被害が 0 か不明かの判別がつきにくいため考慮しな い。また、気象庁の震度(Fig.1)、宇佐美・他 ${ }^{23)}$ の震度分布も用い、 諸井・武村 22) と宇佐美・他 23)で震度が同じ領域は信頼度が高いと考 えた。埼玉県、千葉県、東京都中心部、横浜市に対しては、詳細な

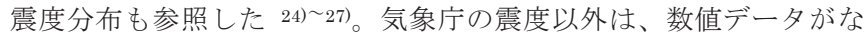

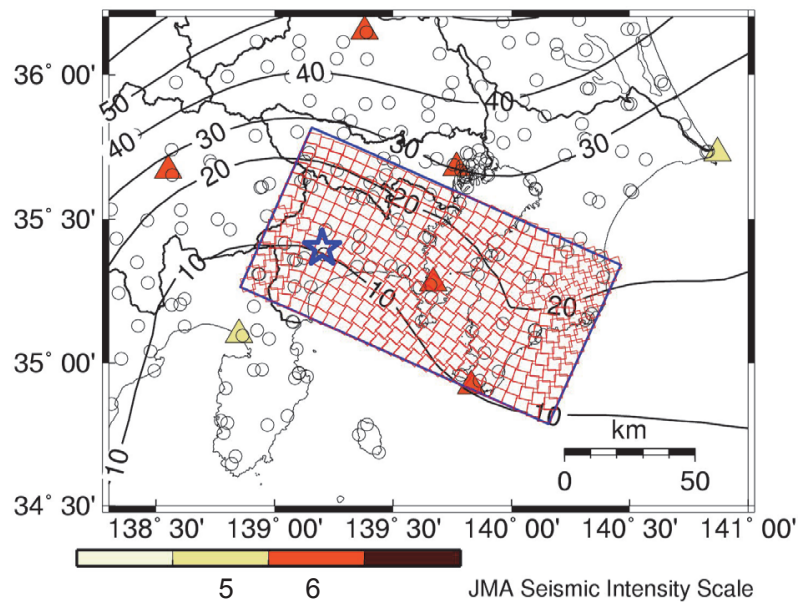

Fig. 1 Fault model of the 1923 Kanto earthquake used in this study (red small squares) and used in Sato et al. ${ }^{18)}$ (a blue rectangle). The epicenter (a star) by Sato et al. ${ }^{18)}$ is used in this study. Triangles are JMA observatories where JMA seismic intensity scales were observed. Circles are strong motion stations used in this study. Contours are the upper depths $[\mathrm{km}]$ of the Philippine Sea plate ${ }^{19)}$.
いため、500 ケース程度の震源モデルに基づく推定震度が、これら 震度分布の図と合うモデルを最適震源モデルとして選択した。

すべり角には、 $\left.140^{\circ} 28\right) を 中 心 に \pm 30^{\circ}$ のばらつきを与えた 20),29),30)。位相も、要素断層毎に変化させた 12 )が、変位波形がパルス 状になる乱数を選択する香川31)の方法を用いているため、位相の違 いによる変位波形のばらつきは小さい12)。同心円状の破壊を仮定し、 破壊伝播速度は $\mathrm{S}$ 波速度の 0.72 倍 32 ) である $2.52 \mathrm{~km} / \mathrm{s}$ とした。

要素断層からの水平・上下動は、(a)〜 (e)の特徵をもつ改良統計的 グリーン関数生成手法 ${ }^{10)}$ で計算する。この改良統計的グリーン関数 は、 $\mathrm{S}$ 波部と後続部、それぞれのフーリエ振幅スペクトル、経時特 性のモデルから成っており、有効周期範囲は 0.05〜 5 秒である。

(a) S 波部のスペクトルモデルは、従来の統計的グリーン関数法と 同様であるが、要素断層毎に周波数、距離依存のラディエーシ ヨン係数が考慮され、経験的地盤増幅率が用いられている。

（b） S 波部の経時特性モデルは、震源特性が Boore $\mathrm{B}^{33)}$ のモデル、伝 播経路特性が $\mathrm{S}$ 波の散乱理論に基づきモデル化され、経験的サ イト係数が用いられている。

（c）後続部のスペクトルモデルは、S 波部に対する比として、震源 距離と震源深さをパラメータとし、各サイトの経験的地盤増幅 率を考慮した回帰式で表現されている。

（d）後続部の経時特性モデルは、実体波とRayleigh 波を考慮した散 乱理論に基づきモデル化され、速度波形の RMS 值に対する経 過時間のべき乗の值が、経験的サイト係数から求められている。

(e) S 波部、後続部、それぞれに対する時刻歴波形を時間領域で足 し合わせて統計的グリーン関数を作成する。

（2）経験的地盤増幅率・サイト係数の面的補間方法

推定された震源モデルを用いて面的に強震動を推定するために、 はじめに、水平動、上下動、それぞれの $\mathrm{S}$ 波部、後続部のスペクト ルの経験的地盤増幅率、経時特性のサイト係数 10)に対して、TZと VS30 をパラメータとした回帰式を作成する。Fig.2 に、 $\mathrm{S}$ 波部水平 動の周期 1 2 秒の経験的地盤増幅率 10)を、推定波形の例を示す観 測点名とともに示す。KNG013(小田原)は、1〜2 秒での増幅率が 10 倍以上である。周期 $0.5 \sim 1$ 秒では 25 倍近くで図中観測点中最大で あった。2〜5秒でも 10 倍以上であった 10)。E58(館山)と CHB021(白

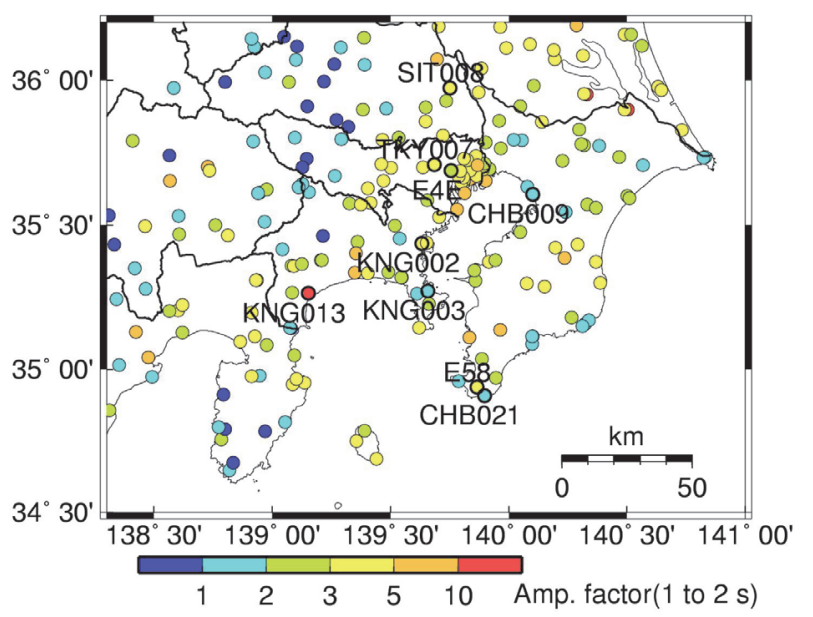

Fig. 2 Empirical amplification factors $G$ in the period of 1 to $2 \mathrm{~s}$ for horizontal components of S-wave windows. Strong motion stations with station names are used in Fig. 7 and Fig. 8 
浜)は近いにもかかわらず、増幅率の違いが大きい。

Fig.3 に、 $T z 、 V S 30$ の分布を示す。 $T z$ は、地震調查研究推進本 部 19)の $1 \mathrm{~km}$ メッシュの三次元地下構造モデルに基づき算出した ${ }^{14)}$ $\mathrm{S}$ 波速度 $V_{S}=3.2 、 1.5 、 0.9 \mathrm{~km} / \mathrm{s}$ の層を基盤としたケースのうち、 最も相関のよい $V_{S}=3.2 \mathrm{~km} / \mathrm{s}$ の地震基盤を用いた $T z$ を用いる。 $V_{S} 30$

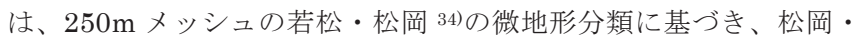
若松 ${ }^{35)}$ の経験式で算出されている J-SHIS のデータを用いた。NGA の地震動予測式例えば 36)では、基盤深さとV $V_{S} 30$ をパラメータとして いるが、基盤深さより相関が良かった $T z$ を用いた。データに基づ き、周波数 $f$ での経験的地盤増幅率 $G(f)$ を(1)、(2)式でモデル化した。 $\log _{10} G(f)=a(f)+b_{1}(f) \log _{10} T Z+c(f) \log _{10} V_{S} 30 \quad T Z \leqq T \operatorname{Tim}(f)$

$\log _{10} G(f)=a(f)+\left(b_{1}(f)-b_{2}(f)\right) \log _{10}(\operatorname{Tlim}(f))+b_{2}(f) \log _{10} T z$

$$
+c(f) \log _{10} V_{S} 30
$$

$T_{Z}>\operatorname{Tlim}(f)$

ここで、 $a 、 b_{1} 、 b_{2} 、 c 、 T l i m$ は回帰係数であり、非線形最小二乗法 で推定した。ただし、S 波部の増幅率以外では、Tlim が周波数によ らず 1 秒程度であったため、Tlim=1 秒として再計算した。また、 データに基づき、 $V_{S} 30=600 \mathrm{~m} / \mathrm{s}$ で頭打ちとした。

次に、以下に示すクリギング手法に基づき、地盤増幅率の面的補 間を行う。(1)、(2)式に基づくモデル地盤増幅率に対する経験的地盤 増幅率の比を Rat $(f)$ とし、 $\left|\log _{10} \operatorname{Rat}(f)\right|$ に対して、(3)式によりセミ バリオグラム久 (d)を算出する。

$$
\gamma(d)=\frac{1}{2 N(d)} \sum_{i=1}^{N(d)}\left(x_{i}-x_{j}\right)^{2}
$$
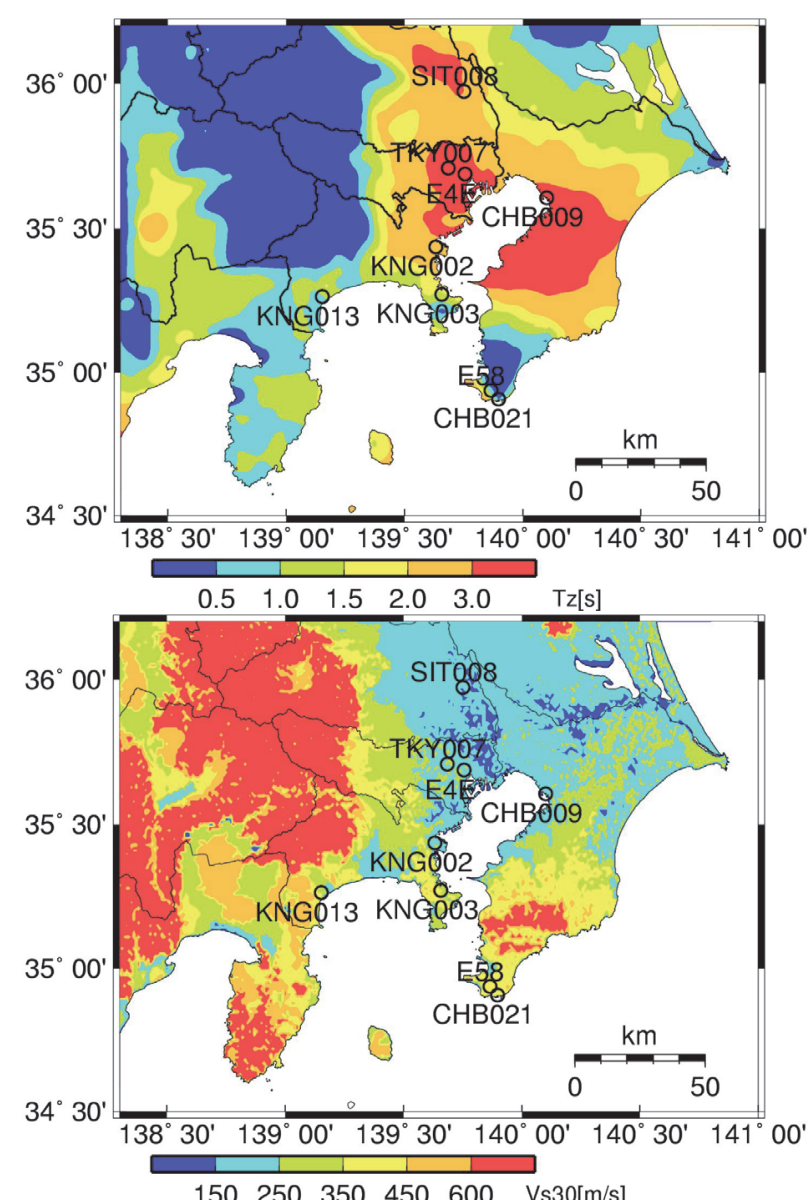

Fig. $3 \mathrm{Tz}^{14), 19)}$ and Vs3034),35) distributions together with the location of strong motion stations used in Fig. 7 and Fig. 8
ここで、 $x_{i} 、 x_{j}$ は、 $i$ 観測点、 $j$ 観測点での $\left|\log _{10} R a t(f)\right| 、 N(d)$ は観 測点間距離 $d \pm 1.25 \mathrm{~km}$ となる観測点ペア数であり、 $2.5 \mathrm{~km}$ 間隔で 久(d)を算出する。そして、久(d)を(4)式の指数モデルにあてはめ、係 数 $p 、 q$ を非線形最小二乗法で推定する。

$$
\chi(d)=q(1-\exp (-d l p))
$$

後述のように、 $d \leqq 15 \mathrm{~km}$ の イ(d)をフィティングの対象とした。 $d$ $\leqq 15 \mathrm{~km}$ の観測点ペア数は 631 個である。

補間地点での推定值 $x_{0}$ は周辺の $K$ 個の観測点の $x_{i}$ の重み付き平 均値として(5)式で算出される。

$$
x_{0}=\sum_{i=1}^{K} \lambda_{i 0} x_{i}
$$

ここで、 $\lambda_{10}$ は、補間地点から一定の距離内にある $i$ 観測点の重み係 数である。 $K$ は、後述の検討に基づき、補間地点からの距離が $15 \mathrm{~km}$ 以内の観測点の数とした。推定誤差の分散 $\sigma^{2}$ は(6)式で表される。

$$
\sigma^{2}=\sum_{i=1}^{K} \lambda_{i 0} \gamma\left(d_{i 0}\right)+\mu
$$

ここで $d_{i 0}$ は $i$ 観測点と補間地点との距離、 $\mu$ は未定係数である。(5)、

(6)式に、重み係数 $\lambda_{i 0}$ の和は 1 という条件を加え、Lagrange の未定 係数法を用いて、補間地点毎に、 $\lambda_{i 0}$ と未定定数 $\mu$ を求める。そして、 $\lambda_{i 0}$ を(5)式に代入し、補間地点での推定值を算出する。

経時特性のサイト係数 $\mu_{t g r}$ site $(f)$ に対しては、(1)、(2)式で $\log _{10} G(f)$ の代わりに $\mu_{t g r}$ site $(f)$ として回帰式を作成する。そして、回帰式から のサイト係数の差に対してれ(d)を算出し、補間地点での推定值を算 出する。

\section{3．＼cjkstart強震動生成域と強震観測点での震度推定結果}

Fig.4(a)には、地盤の非線形性を考慮して推定した強震動生成域 の要素断層の中心点位置と震度分布を示寸。Fig.4(b)には、この震 源モデルを用いて地盤の非線形性を考慮せず推定した震度分布を示 す。地盤の非線形性を考慮した場合、Fig.5 に示した諸井・武村 22$)$ の震度分布の震度 7 と 6 強の領域をほぼ再現しており、埼玉県東部 で震度が大きくなる特徵を捉えている。また、横浜の観測点 KNG002 と気象庁観測点 E56 は、高浜・他 27)の木造家屋の全壊率 が $50 \%$ 以上の地域にあり 27 、震度に換算すると 7 となることから、 推定震度と整合する。東京中部、東京・神奈川県境付近では、諸井・ 武村 22) よりやや大きいが、宇佐美・他 23) とはほぼ合っている。一方、 地盤の非線形性を考慮しない場合には、震度 7 や 6 強の範囲が諸 井・武村 22)の震度分布より広い。地盤の非線形性を考慮せず、震度 7 や 6 強の範囲が諸井・武村 22)の震度分布と合うように震源モデル を推定すると、埼玉県など遠方で過少評価となった。壇・他 ${ }^{2)}$ の統 計的グリーン関数法や、松島・他 ${ }^{5}$ のハイブリッド法による震度分 布の震度 7 の領域は諸井・武村 22)に比べてやや狭く、埼玉県東部の 震度も諸井・武村 22) に比べてやや過少評価である。秋山・他 ${ }^{4)} の 八$ イブリッド法による震度分布は、千葉県側が本研究よりやや大きい。

Fig.1.の気象庁の震度と比較すると、埼玉県北部と銚子付近では、 気象庁の震度と近傍の強震観測点の推定值が異なっている。 Fig.4(a)の近接する強震観測点でも、震度が 2 階級以上異なる場合 があることから、気象庁の震度観測点と強震観測点でのサイト特性 の違いにより差が生じている可能性がある。また、経験的地盤増幅 率・サイト係数が震源距離 $100 \mathrm{~km}$ 以下の記録から算出されている 


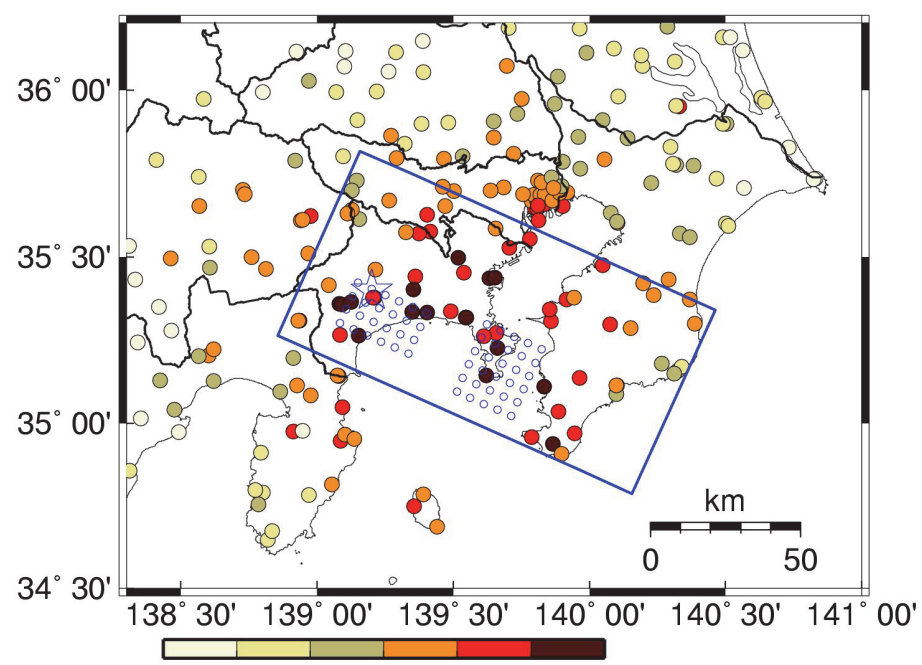

$\begin{array}{lllll}4.5 & 5.0 & 5.5 & 6.0 & 6.5\end{array}$

(a) With consideration of non linear Seismic Intensity

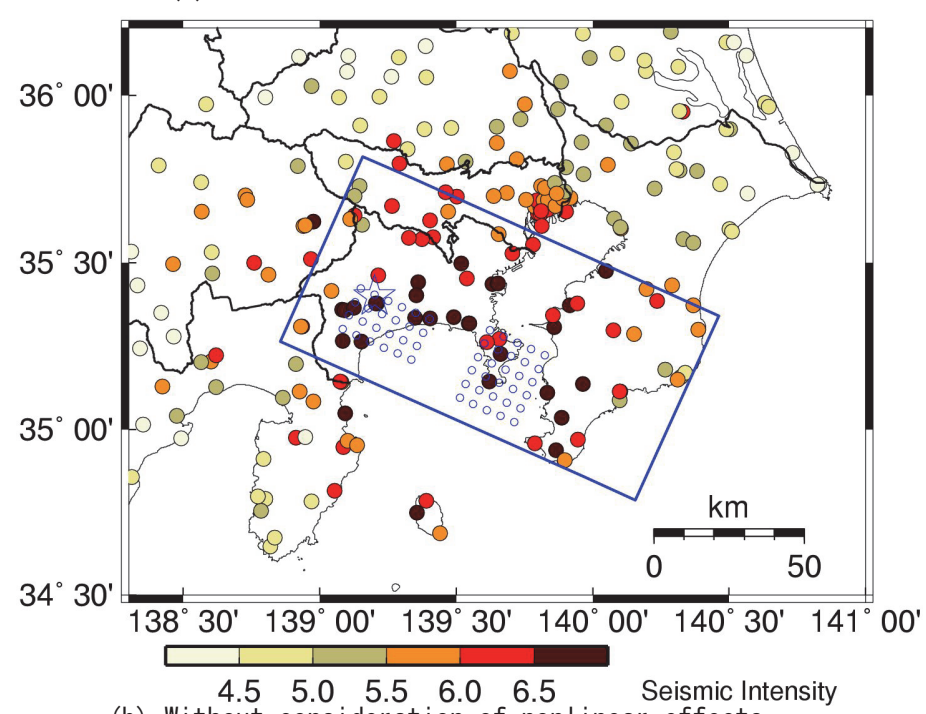

(b) Without consideration of nonl inear effects

Fig.4 Estimated instrumental seismic intensity. Blue small circles denote the centers of elements for two strong motion generation areas

\section{ため、遠方で外捜になっていることも原因として考えられる。}

推定した強震動生成域は、2つのす心゙り量が大きい領域 18 )付近に ある。一方、中央防災会議 7の統計的グリーン関数法による計算で は、江東区直下付近や房総半島南端直上を含む 5 つの強震動生成域 を設定し、都心部や埼玉県の東部や房総半島南端での震度の大きい 領域を再現している。この違いの原因として、中央防災会議 7)の統 計的グリーン関数法では、表面波の影響が考慮されていないこと、 工学的基盤以浅の増幅度を経験式で計算していること、震度に対す る地盤の非線形性の影響を考慮していないことが考えられる。

Table1に、推定した震源パラメータを示す。SMGA1(西側の強震 動生成域)の応力降下量 $\Delta \sigma$ は $14.5 \mathrm{MPa} 、 \mathrm{SMGA} 2$ (東側の強震動生成 域)の応力降下量は $21.8 \mathrm{MPa}$ である。中央防災会議 7では、 5 つの 強震動生成域の応力降下量を $25 \mathrm{MPa}$ としている。短周期レベル $A$ は、本研究では強震動生成域のみで $6.0 \times 10^{19} \mathrm{Nm}$ 、背景領域を含め て $6.4 \times 10^{19} \mathrm{Nm}$ であるのに対して、中央防災会議 7では強震動生成 域のみで $1.05 \times 10^{20} \mathrm{Nm}$ である。この違いの原因として、本研究で は経験的地盤増幅率を、中央防災会議 7)では 1 次元理論地盤増幅率

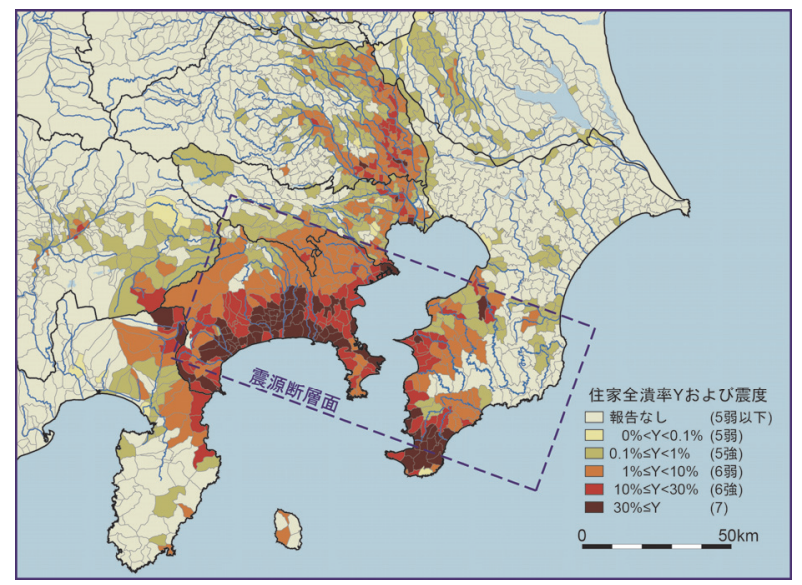

Fig. 5 Seismic intensity estimated from total collapse ratios of wooden houses by Moroi and Takemura ${ }^{22)}$
Table 1 Fault parameters

\begin{tabular}{|c|c|c|c|c|c|c|c|c|c|}
\hline \multicolumn{3}{|c|}{ SMGA1(west) } & \multicolumn{3}{|c|}{ SMGA2 (east) } & \multicolumn{2}{c|}{ Background } \\
\hline Length & Width & $\mathrm{M}_{0}$ & $\Delta \sigma$ & Length & Width & $\mathrm{M}_{0}$ & $\Delta \sigma$ & $\mathrm{M}_{0}$ & $\Delta \sigma$ \\
\hline $\mathrm{km}$ & $\mathrm{km}$ & $\mathrm{Nm}$ & $\mathrm{MPa}$ & $\mathrm{km}$ & $\mathrm{km}$ & $\mathrm{Nm}$ & $\mathrm{MPa}$ & $\mathrm{Nm}$ & $\mathrm{Mpa}$ \\
\hline 30.0 & 20.0 & $1.24 \mathrm{E}+20$ & 14.5 & 25.0 & 30.0 & $1.73 \mathrm{E}+21$ & 21.8 & $7.03 \mathrm{E}+20$ & 2.9 \\
\hline
\end{tabular}

1923 Kanto earthquake(This study)

OInterplate earthquakes along the Sagami Trough(Satoh,2014) $\star 1987$ Chiba-ken-toho-oki earthquake(Satoh,2014)

in Intraslab earthquakes along the Sagami Trough(Satoh,2015) ₹2011 Tohoku earthquake(Satoh,2012)

- Interplate earthquakes along the Japan Trench(Satoh et al.,2010) — Crustal earthquakes(Dan et al.,2001)

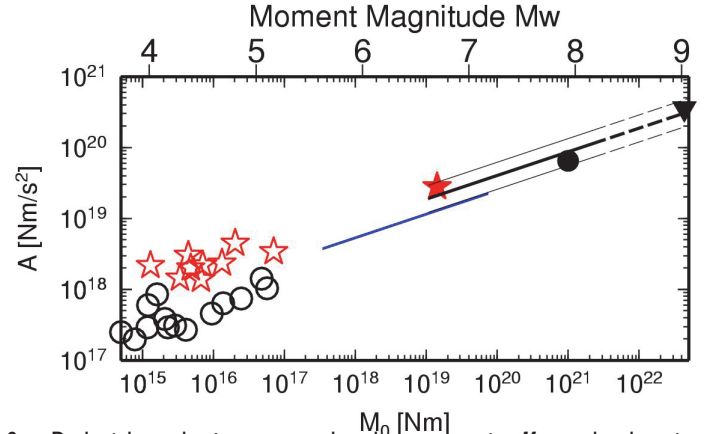

Fig. 6 Relation between seismic moment $M_{0}$ and short-period spectral level of acceleration source spectra $A$

を用いているという違いが考えられる。すなわち、 $\mathrm{S}$ 波部の経験的 地盤増幅率の方が 1 次元理論地盤増幅率より大きい傾向がある 10 ため、本研究の短周期レベルの方が小さいものと考えられる。

Fig.6 には、推定した 1923 年関東地震の短周期レベル $A(6.4 \times$ $10^{19} \mathrm{Nm}$ ) と地震モーメント $M_{0}$ の関係を、既往の $M_{0}-A$ の関係ととも に示寸。1923 年関東地震の $A$ は、東北地方太平洋沖地震の $A^{37)}$ ほぼ説明する日本海溝沿いのプレート境界地震 38$) の 0.74$ 倍、地款 内地震 ${ }^{3)} 1.21$ 倍である。これは、1923 年関東地震が日本海溝沿 いのプレート境界地震に比べ、震源深さが浅いことが影響している 可能性がある。また、スラブ内地震である 1987 年千葉県東方沖地 震 $\left.(M \mathrm{~s} 6.7){ }^{12}\right)$ の 0.55 倍である。これは、相模卜ラフ沿いのフィリピ ン海プレートの中規模地震でも、プレート境界地震の方がスラブ内 地震より $A$ が小さいという関係 ${ }^{11}$ と同じである。1923 年関東地震 の $A$ は、相模トラフ沿いのフィリピン海プレートの中規模プレート 境界地震の $M_{0}-A$ 関係より大きいという規模依存例え涪 38 ) もみられる。 
巨視的断層の面積に対する強震動生成域の面積の比は $14.8 \%$ あ゙あ、 地款内地震 39 ) よりさく、日本海溝沿いのプレート境界地震 38 よりり 大きい。また、1987 年千葉県東方沖地震 ${ }^{12)}$ より大きい。

\section{4. 強震観測点での強震動波形推定結果}

Fig.2、Fig.3に観測点名を示した 9 観測点における、地盤が線形 時の地表での計算波形から、水平動に対しては $\mathrm{S}$ 波の、上下動に対 しては $\mathrm{P}$ 波の 1 次元理論地盤増幅率を、 $V_{S} \geqq 500 \mathrm{~m} / \mathrm{s}$ の工学的基盤 での波形を計算する。水平動に対しては、この工学的基盤波を用い て、吉田 40)の改良等価線形解析プログラム DYNEQ により、地盤の 非線形を考慮して、地表での波形を推定する。上下動の地表の波形 は、地盤が線形時の波形をそのまま用いる。

地下構造モデルは、佐藤 10)で用いた中規模地震記録の S 波部の $\mathrm{H} / \mathrm{V}$ の平均值をターゲットとして、以下の条件で、拡散波動場理論 41)に基づき同定 ${ }^{42)}$ した。 $V_{S}=3200 \mathrm{~m} / \mathrm{s}$ の地震基盤から $V_{S}=500 \mathrm{~m} / \mathrm{s}$
の工学的基盤までの深部地盤は、地震調査研究推進本部 19)の三次元 地下構造モデルを用いた。浅部地盤は、K-NET 観測点では PS 検層 結果、気象庁 95 型震度計観測点では近傍の地盤調查結果 43,44 ) に基 づく $N$ 值から換算した $V S$ 構造を初期モデルとした。 $\mathrm{P}$ 波速度 $V p$ や密度が未知の場合は、経験式 45),46)から換算した。浅部構造の最深 $V_{S}$ の下に、その $V_{S}$ より大きい深部構造を繋げ、その境界層の深さ と浅部地盤の $V_{S}$ を推定パラメータとした。減衰 $h$ は、浅部は $h=5 / V_{S}($ ただし、 $h \leqq 0.03)$ とし、深部は地震調查研究推進本部 19)の $Q s$ 值から換算した。関東平野の堆積地盤の $\mathrm{P}$ 波と $\mathrm{S}$ 波の $h$ は、 $4 \mathrm{~Hz}$ 以上で同程度である ${ }^{47)} こ$ こら、 $\mathrm{P}$ 波の $h$ は $\mathrm{S}$ 波と同じとした。

DYNEQ40)による等価線形解析では、土に対しては安田・山口 ${ }^{48)}$ の土質と拘束圧依存の動的変形特性、堆積軟岩に対しては福元 - 他 49)の塑性指数 $20 \sim 40$ の場合の動的変形特性を用いた。ただし、減 衰 $h$ には、線形時の減衰以上という条件をつけた。

Fig.7 には、推定した地表と工学的基盤での加速度波形、速度波

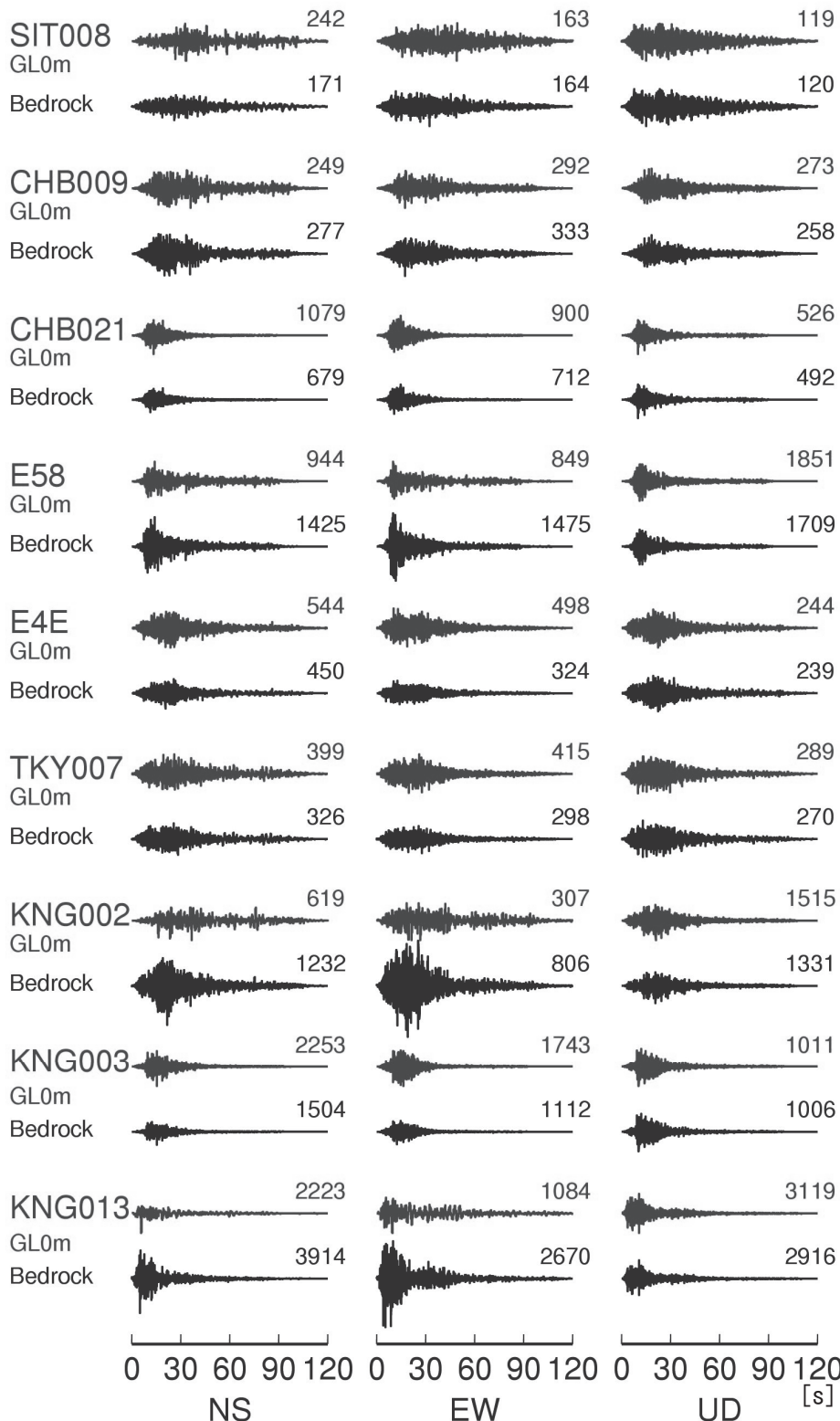

(a) Acceleration

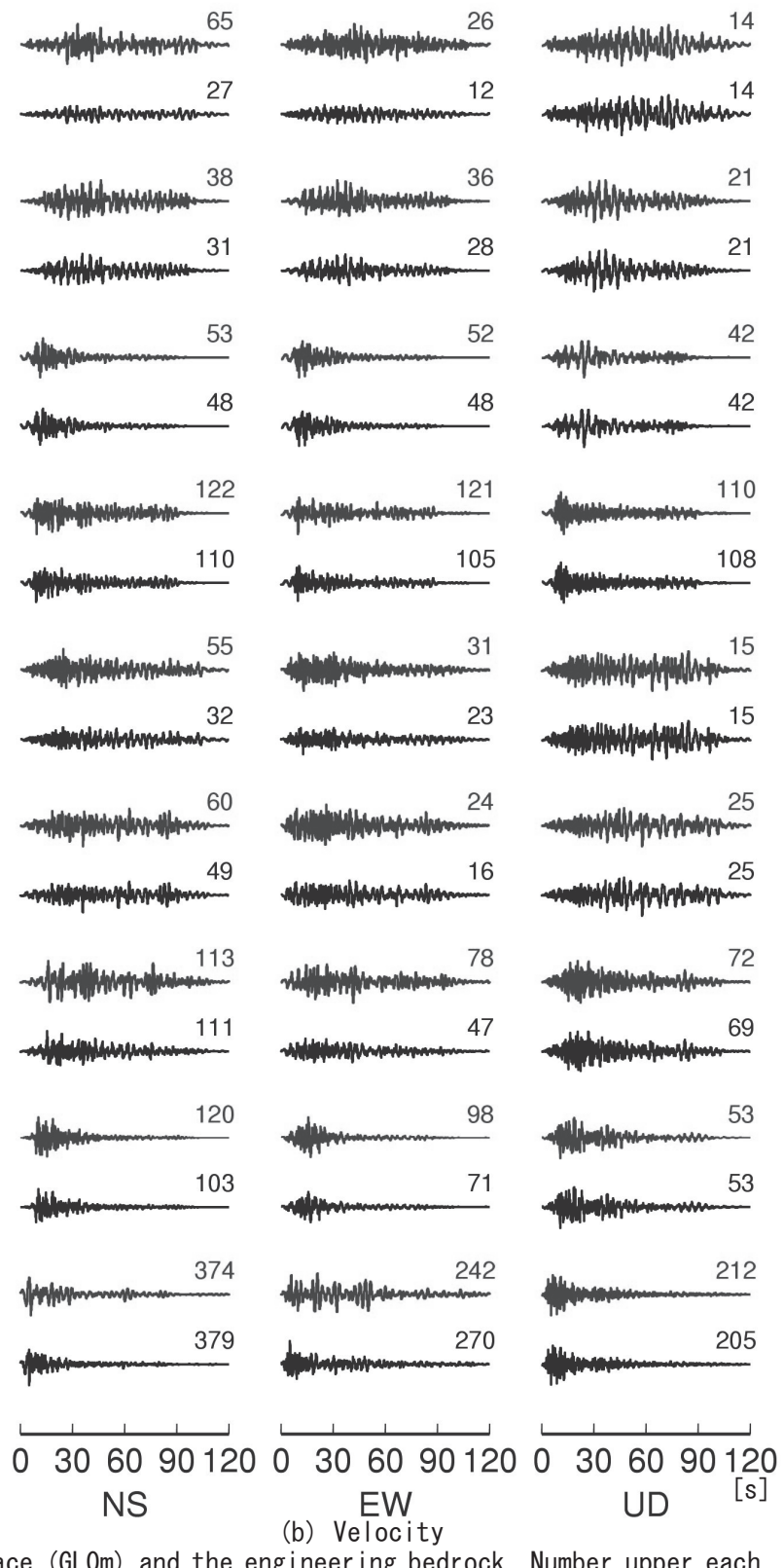

(b) Velocity

Fig. 7 Acceleration and velocity time histories estimated at the surface (GLOm) and the engineering bedrock. Number upper each time history is peak ground acceleration $\left[\mathrm{cm} / \mathrm{s}^{2}\right]$ and peak ground velocity $[\mathrm{cm} / \mathrm{s}]$. 
形を示す。いずれも、0.2 $20 \mathrm{~Hz}$ のフィルター波である。工学的基 盤の波形は地表の波形の最大振幅值で基準化して表示した。従来の 統計的グリーン関数法による推定波 ${ }^{2), 4}$ は、都心部でも速度波形の 継続時間が 20 秒程度であるが、本研究では、表面波と散乱波の影
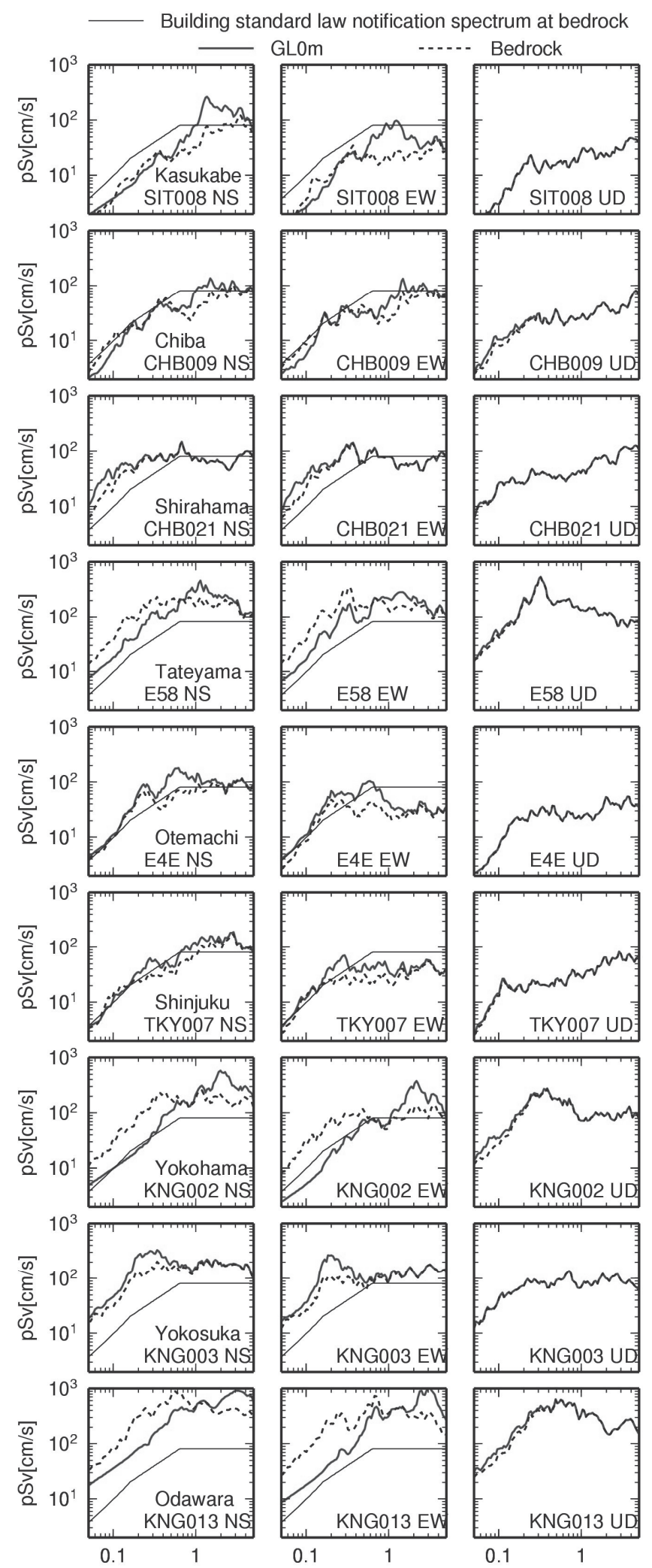

Period [s]
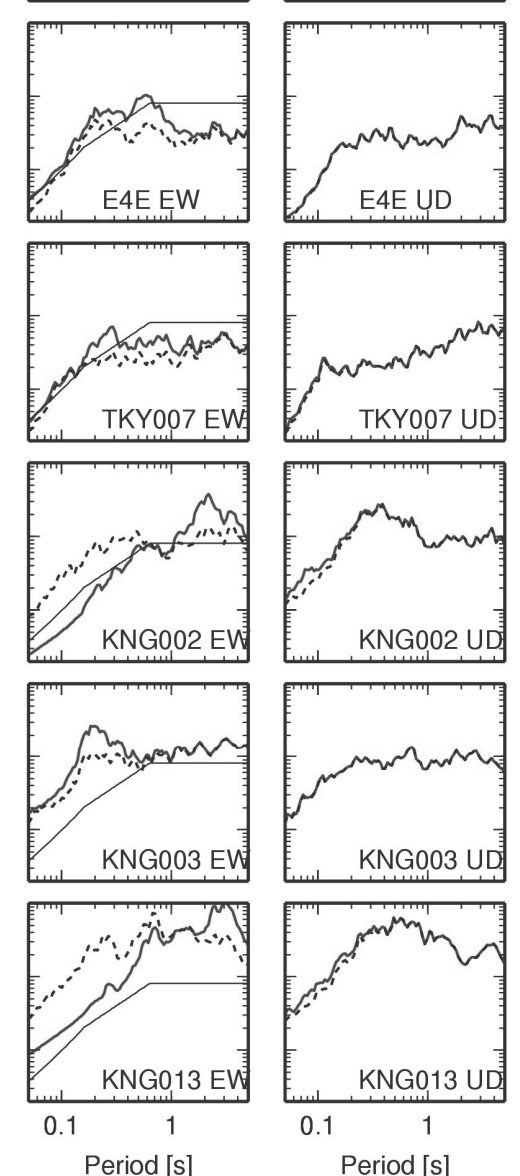

Fig. 8 Pseudo velocity response spectra $(h=5 \%)$ at the surface (GLOm) and the engineering bedrock.
響が考慮されているため 100 秒程度と長い特徵がある。

KNG013 は、上述のように地盤増幅率が非常に大きく、直下 $7 \mathrm{~km}$ という浅い位置に SMGA1(西側の強震動生成域)がある。このよう な原因により、全観測点の中で地震動レベルが最大で、加速度波形、 速度波形とも非常に大きかったと考えられる。ただし、地表近くで ひずみレベルが 10\%に達しており、ひずみが 1\%を超える大ひずみ 領域での動的変形特性がほとんどわかっていない 50)ため信頼性が 低い。吉田 ${ }^{51)}$ が指摘しているように、このようなモデル化の問題が あるため、非線形解析手法を導入したとしても精度よい推定は困難 である。SMGA2(東側の強震動生成域)の直上にある KNG003(横須 賀)でも、地表の水平動の最大加速度が $2000 \mathrm{~cm} / \mathrm{s}^{2}$ 前後、最大速度が $100 \sim 120 \mathrm{~cm} / \mathrm{s}$ と大きい。KNG003の推定震度は、地盤が線形時と 非線形時の計測震度の関係式 13) では 6 強、推定波形からは 7 であっ た。KNG002(横浜)と E58(館山)の地表での水平動の大きい方の最大 速度は $110 \sim 120 \mathrm{~cm} / \mathrm{s}$ である。KNG002 では、地盤が線形時と非線 形時の計測震度の関係式 13) では 7(計測震度 6.5)、推定波形からは 6 強(計測震度 6.4)であり、E58 では両手法とも震度 7 であった。地盤 が線形時と非線形時の関係式は、震度 7 のデータが少ないという久 点があり、地表での推定波形には、非線形解析のモデル化等に久点 があるため、多少の違いが生じている。水平動の最大速度が大きか った観測記録として、2004 年新潟県中越地震 $\left(M_{\mathrm{J}} 6.8\right)$ の川口町役場 の $146 \mathrm{~cm} / \mathrm{s} 、 1995$ 年兵庫県南部地震 $\left(M_{\mathrm{J}} 7.3\right)$ の $\mathrm{JR}$ 鷹取の $136 \mathrm{~cm} / \mathrm{s}$ 、 東北地方太平洋沖地震の仙台市七鄉小学校の $116 \mathrm{~cm} / \mathrm{s}$ などがあり、 いずれも震度 7 相当であった。また、水平動の最大加速度が $1500 \mathrm{~cm} / \mathrm{s}^{2}$ を越える記録は多数観測されている。上下動も、KNG002 の最大加度度、最大速度は、震度 7 相当の 2000 年鳥取県西部地震 (MJ7.3)の TTRH02(日野)と同レベルである。一方、東京都心部の TKY007(新宿)、E4E(大手町)の地表では、水平動の最大加速度は 400 $\sim 550 \mathrm{~cm} / \mathrm{s}^{2}$ で、最大速度は、NS 成分で $55 \sim 60 \mathrm{~cm} / \mathrm{s} 、 \mathrm{EW}$ 成分で $25 \sim 30 \mathrm{~cm} / \mathrm{s}$ である。また、地盤増幅特性の違いを反映し、近接す る E58(館山)と CHB021(白浜)の波形には大きな違いがある。

Fig. 8 には、地表と工学的基盤での波形の擬似速度応答スペクト
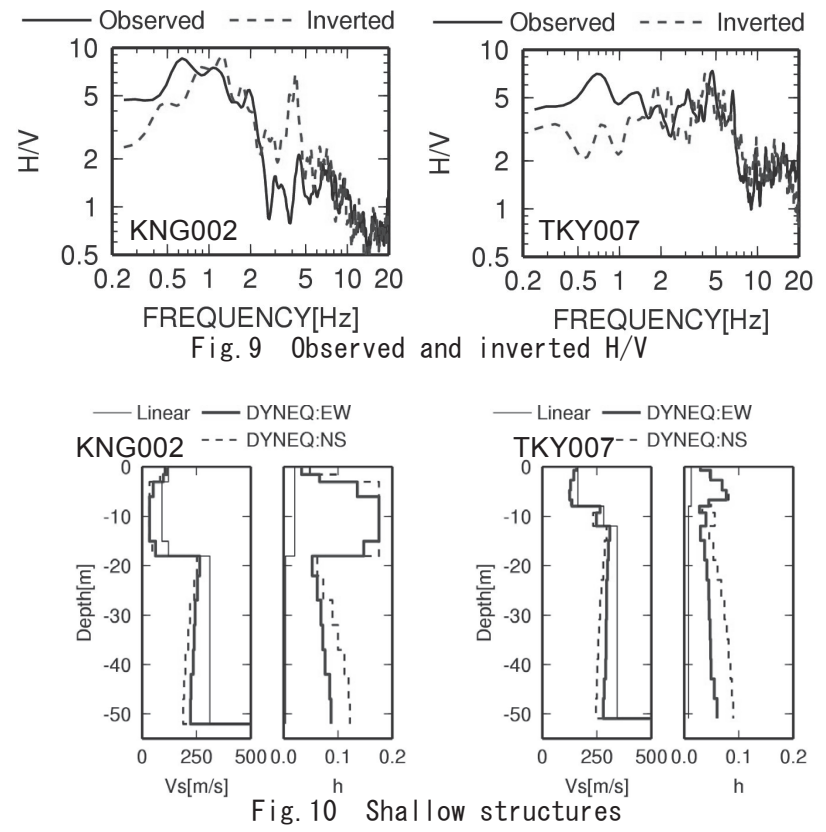
ル(減衰定数 5\%)を示す。KNG002、E58 の地表での水平動は、周期 $1 \sim 2$ 秒で $500 \mathrm{~cm} / \mathrm{s}$ 程度に達し、2004 年新潟県中越地震 $\left(M_{\mathrm{s}} 6.8\right)$ で震 度 7 となった川口町役場や NIG019(小千谷)に匹敵するレベルであ る。一方、TKY007、E4E では、工学的基盤の NS 成分が、工学的 基盤での告示スペクトルのうちの極めて稀に発生する地震動(レベ ル 2) と同レベルである。埼玉県東部の SIT008(春日部)では、周期 1 秒前後で工学的基盤から地表までの増幅が大きく、震度 6 弱となっ たと考えられる。また、E58、SIT008 周辺の木造建物が NS 方向に

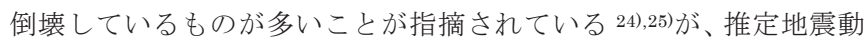
も NS 成分の方が EW 成分より大きい結果となっている。

Fig.9 には、例として KNG002(横浜)と TKY007(新宿)での観測 $\mathrm{H} / \mathrm{V}$ と理論 $\mathrm{H} / \mathrm{V}$ の比較を示す。低周波数側でやや合わないのは、観 測に表面波が含まれているためと考えられる。Fig.10には、線形時 の浅部地盤モデルと、DYNEQ での解析に基づく等価な浅部地盤モ

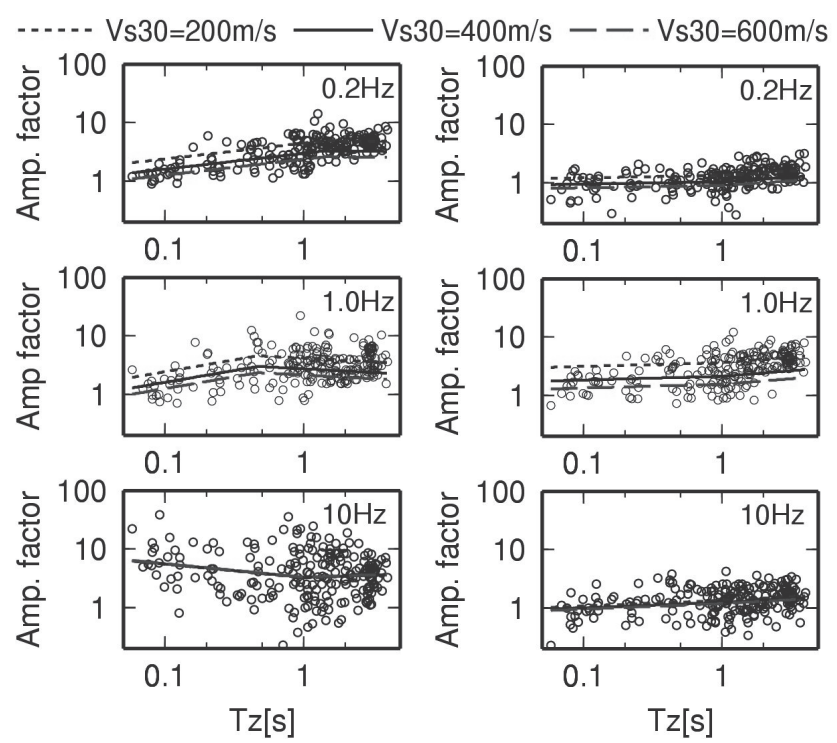

Fig. 11 Observed (circles) and model (Iines) relations between $\mathrm{Tz}$ and amplification factors $G$ for $S$-wave windows (left) and later time windows (right)
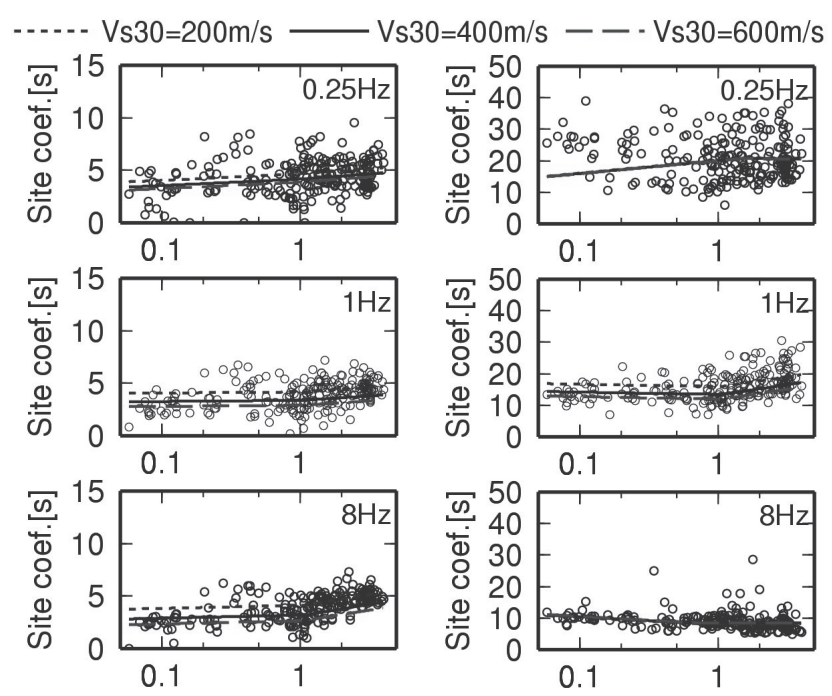

$\mathrm{Tz}[\mathrm{s}]$

$\mathrm{Tz}[\mathrm{s}]$

Fig. 12 Observed (circles) and model (I ines) relations between $T z$ and site coefficients $\mu_{\text {tgr }}$ site for $S$-wave windows (left) and later time windows (right)
デルを示す。DYNEQ は $1 \%$ 前後まで有効な手法であるため 40 、 KNG002 での地表の推定波形はやや精度が悪い可能性がある。

\section{5. 経験的地盤増幅率・サイト係数の面的補間の経験式}

面的強震動予測のための、面的補間法の検討結果を以下に示す。 Fig.11には、S 波部、後続部の水平動に対する、 $T z$ と地盤増幅率 $G$ の関係を、回帰式とともに示す。 $0.2 \mathrm{~Hz} 、 1 \mathrm{~Hz} 、 10 \mathrm{~Hz}$ の例である。 $\mathrm{S}$ 波部の増幅率は、 $10 \mathrm{~Hz}$ では、 $T z$ が 1 秒程度以下で、 $0.2 \mathrm{~Hz} 、 1 \mathrm{~Hz}$ と逆の傾きになっている。これは、Tzの小さい地点で、薄い堆積地 盤により高周波数が増幅されるためと考えられる。なお、 $\mathrm{S}$ 波部の $1 \mathrm{~Hz}$ での増幅率が $T z=1$ 秒弱で最も大きいのが KNG013である。後 続部は、 $\mathrm{S}$ 波部に対するスペクトル比で定義されているため、その 地盤増幅率の $T z$ 依存性は小さい。また、 $\mathrm{S}$ 波部、後続部とも、 $0.2 \mathrm{~Hz}$ 、 $1 \mathrm{~Hz}$ ではV V 30 が小さいほど増幅率が大きくなるが、 $10 \mathrm{~Hz}$ では $V_{S} 30$ 依存性が小さい。川瀬・松尾 ${ }^{52}$ は、 $5 \sim 10 \mathrm{~Hz}$ の経験的地盤増幅率が $V_{S} 5$ (深さ $5 \mathrm{~m}$ までの平均 $V_{S}$ ) と相関が良いことを指摘しているよう に、 $10 \mathrm{~Hz}$ ではより浅い地盤の影響が大きいためと考えられる。

Fig. 12 には、 $\mathrm{S}$ 波部、後続部の水平動に対する、 $T z$ と経時特性の サイト係数 $\mu_{t g r}$ site の関係を、回帰式とともに示す。サイト係数は $1 / 2$ オクターブバンド毎に算出されており、その中心周波数 $0.25 \mathrm{~Hz}$ 、 $1 \mathrm{~Hz} 、 8 \mathrm{~Hz}$ の例である。サイト係数は、 $\mathrm{S}$ 波部では、Tzが大きいほ ど継続時間が伸びることがわかる。後続部は、 $8 \mathrm{~Hz}$ ではサイトによ る違いは小さく $T z$ 依存性も小さい。これは、後続部の高周波数帯 域では、堆積層より、地殼やプレートでの不均質性の寄与が大きく、 実体波の散乱波が主たる波群であるためと考えられる。一方、後続 部の $0.25 \mathrm{~Hz}$ ではばらつきが大きく、これは、深部・浅部地盤の三 次元地下構造の影響が大きく、位相や継続時間の方が振幅よりその 影響を受けや寸いためと考えられる。

Fig.13には、S 波部の水平動に対する地盤増幅率、サイト係数の モデルからの残差のセミバリオグラム $\gamma$ を示す。地盤増幅率の $\gamma$ は、 距離 $d=5 \sim 10 \mathrm{~km}$ でほぼ一定值となる、すなわち、 $p=5 \sim 10 \mathrm{~km}$ とな る。後続部の地盤増幅率にも同様の特徽があった。サイト係数の の $p$ は $15 \mathrm{~km}$ 前後である。なお、後続部の 9 の $p$ は、 $0.25 \mathrm{~Hz}$ 以外 $0 \mathrm{~km}$
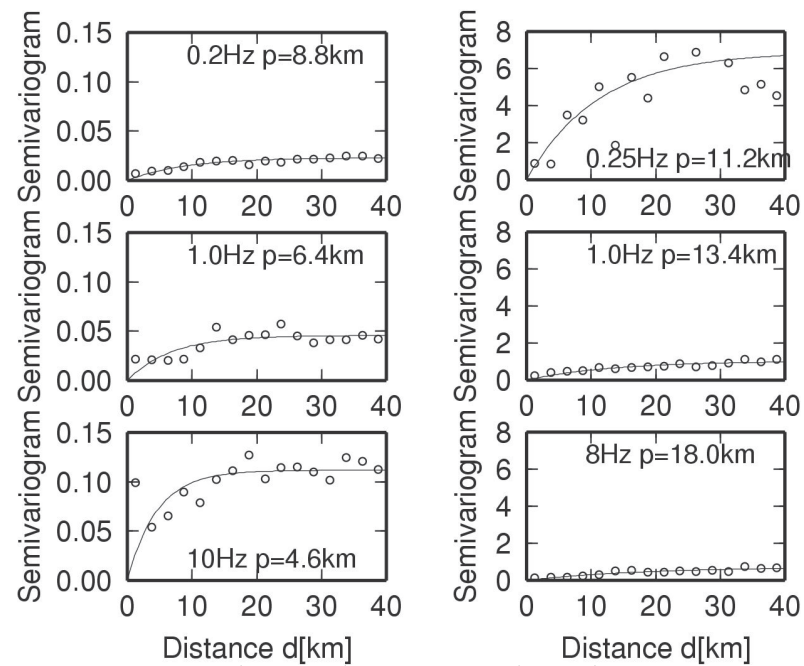

Fig. 13 Observed (circles) and model (I ines) semivariogram $\gamma$ for residuals of amplification factors $G$ (left) and site coefficients $\mu_{\text {tgr }}$ site (right) for horizontal components of S-wave windows 
に近かった。これは、地殼やプレートでの不均質性の影響を受けた 散乱波が卓越するためると考えられる。なお、 $\mathrm{S}$ 波部、後続部とも、 水平動、上下動の違いは小さかった。ほぼ $p<15 \mathrm{~km}$ であるため、(5) 式で補間を行う範囲を $15 \mathrm{~km}$ 以下と設定している。

\section{6. 面的強震動推定結果と本郷での復元記録との比較}

東京大学が観測した今村式 2 倍強震計の変位記録が得られている 本郷(Hongo)53)が含まれる 2 次メッシュの領域で、面的補間法を用 いて推定した $250 \mathrm{~m}$ メッシュの面的震度分布を Fig.14 に示す。四捨 五入する前の計測震度を用いた。 $10 \mathrm{~km}$ 四方の狭い領域でも震度 5 強〜 6 強の違いがあり、平均的には武村 26)の震度分布と整合する。 しかし、武村 26 )の震度分布では、震度 7 や震度 5 弱の領域もあるが、 これは再現されていない。この原因として、TzとV $V_{S} 30$ 自体が平均 的な指標であり、TzとV $V_{S} 30$ を用いた経験的地盤増幅率、サイト係 数の回帰式も平均的なものであることが考えられる。震度 7 や震度 5 弱の領域に強震観測点がなかったことも原因として考えられる。 対象地点の浅部地盤構造が既知で、近傍強震観測点と大きく異なる 場合は、近傍観測点での推定強震動波形を、1 次元理論地盤増幅率 を用いて補正するなどの個別の検討が必要と考えられる。

Fig.15、Fig.16 には、本郷(Hongo)での推定波の加速度波形・速 度波形、擬似速度応答スペクトル(減衰定数 $5 \%$ ) を示す。復元波は E13 成分 ${ }^{17)}$ であるため、推定波もこの方向に変換した。前述の強震 観測点での検討と同様に、工学的基盤波と、水平成分に対しては DYNEQ を用いて推定した地表での波形である。E4E(大手町)の推 定波形(Fig.7)より振幅がやや小さいが、類似した波形となっている。 Fig.17 には、PS 検層結果 54)に基づく線形時の浅部地盤モデルと、 DYNEQ での解析に基づく等価な浅部地盤モデルを示す。

Fig.18には、推定波と復元波の速度応答スペクトル(減衰定数 $5 \%$ ) の比較を示す。振動実験に基づき、復元波は $15 \%$ ほど過少評価とな っていると指摘されている17)ため、1.15 倍したスペクトルも示した。 復元波は、周期 $2 \sim 15$ 秒で信頼できると記述されている ${ }^{17) か ゙ 、 ~} \mathrm{E} 13^{\circ}$ $\mathrm{N}$ 成分の推定波は復元波と周期 $0.5 \sim 5$ 秒でほぼ合っている。推定 波の方が周期 2〜 5 秒でやや大きいが、復元波の一部は欠落したま まであることが影響している可能性もある。N13 W と UD成分は、 大きく振り切れ、復元できる波形でなかった ${ }^{17)}$ 。しかし、余震記録 の変位振幅が、 $\mathrm{N} 13^{\circ} \mathrm{W}$ 成分が $\mathrm{E} 13^{\circ} \mathrm{N}$ 成分の約 1.5 倍であること

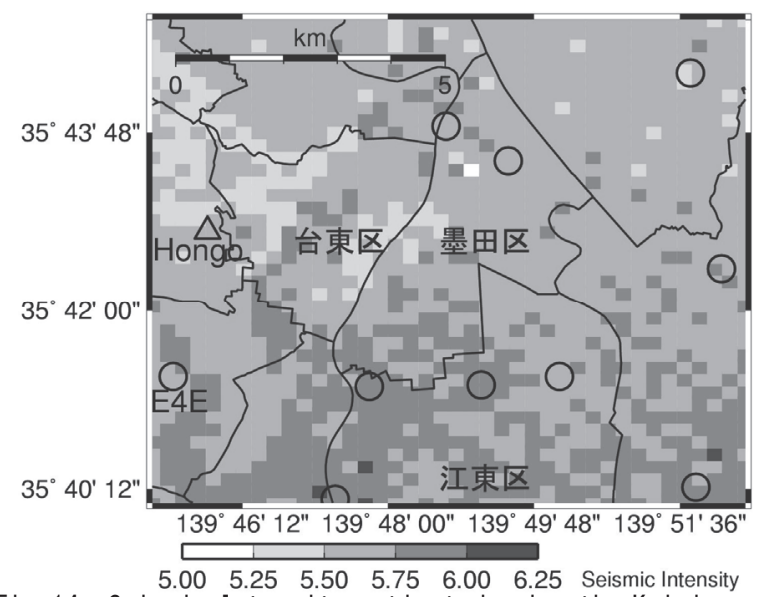

Fig. 14 Seismic Intensity estimated using the Kriging method. Circles denote strong motion stations.

などから、本震の主要動部もこの程度の違いがあると考えられてい る 17)。一方、推定波の $\mathrm{N} 13^{\circ} \mathrm{W}$ 成分のスペクトルも、周期 1 秒程 度以上で $\mathrm{E} 13^{\circ} \mathrm{N}$ 成分の約 1.5 倍となっている。

Fig.19には、1200 秒間復元されている復元波(周期 0.5〜 15 秒の 速度フィルター波) 17)の 300 秒間を示寸。矢印の 2 か所の欠落部は 修復されていない17)。Fig.20 には、復元波と推定波の周期 0.5〜 5 秒の速度波形を示す。改良統計的グリーン関数生成に用いている強 震波形の記録継続時間が短いため、 $\mathrm{S}$ 波初動から 80 秒間のみがモデ ル化されている10)ことから、推定波の継続時間は十分ではないが、 復元波の振幅が大きい時間帯をほぼ再現している。

地表での推定波と 1.15 倍した復元波を、接続周期 4.5 秒でハイブ リッドした。建築物に対する入力地震動としては、振幅の小さい $\mathrm{E} 13^{\circ} \mathrm{N}$ 成分の夕を考慮するのは不適当と考え、 $\mathrm{N} 13^{\circ} \mathrm{W}$ 成分につ いては、1.15 倍した復元波を 1.5 倍した波形を用いてハイブリッド 波を作成した。Fig.21 には、ハイブリッドした周期 0.05〜15 秒の 速度波形と、微分した加速度波形を示す。改良統計的グリーン関数 法のみで推定した波形(Fig.15) とは、後続部の継続時間に違いある が、最大加速度、最大速度の違いは小さい。他の地点で、周期 5 秒 以上の地震動が必要な場合には、本研究での推定波と三次元有限差

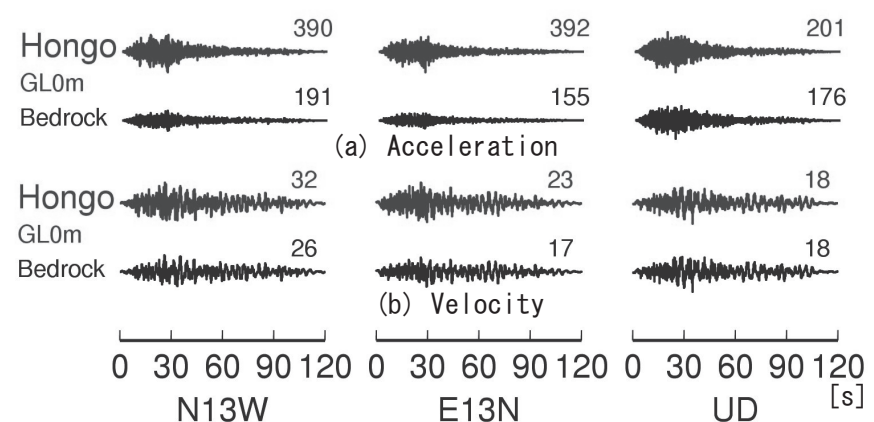

Fig. 15 Acceleration and velocity time histories estimated at the surface $(\mathrm{GLOm})$ and the engineering bedrock at Hongo

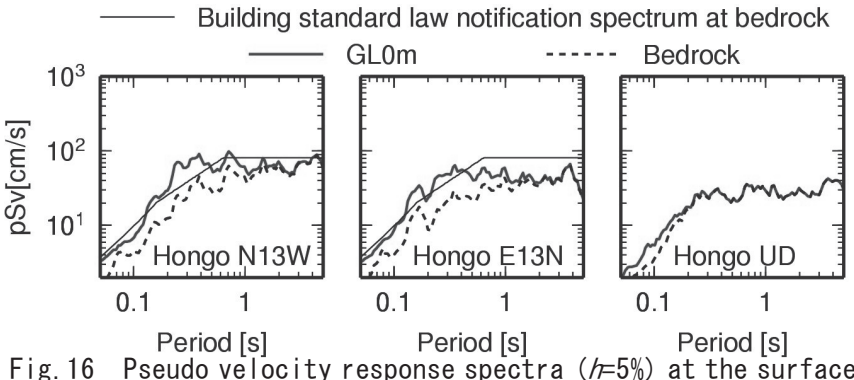
Fig. 16 Pseudo velocity response spectra $(h=5 \%)$ at the surface (GLOm) and the engineering bedrock at Hongo

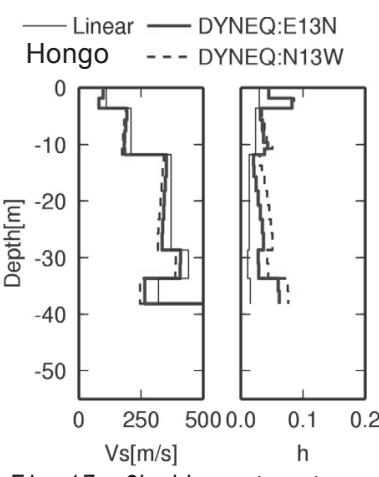

Fig. 17 Shallow structure

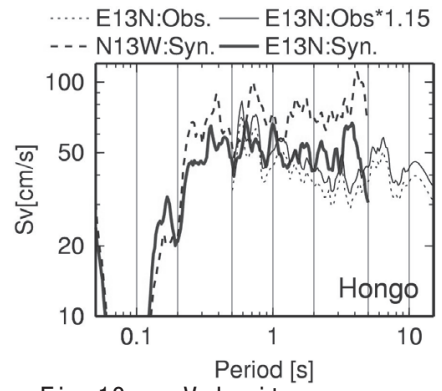

Fig. 18 Velocity response spectra $(h=5 \%)$ at the surface of the restored record and estimated strong motions 


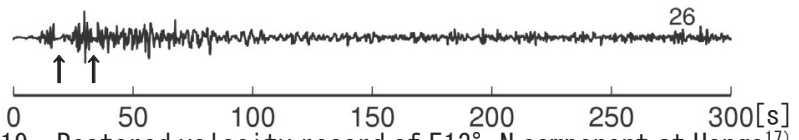

Fig. 19 Restored velocity record of $\mathrm{E} 13^{\circ} \mathrm{N}$ component at Hongo ${ }^{177}$

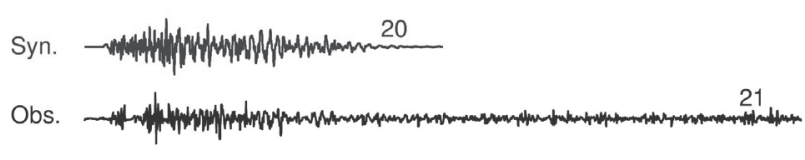

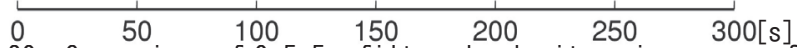
Fig. 20 Compar ison of $0.5-5 \mathrm{~s}$ filtered velocity se i smograms of $\mathrm{E} 13^{\circ} \mathrm{N}$ component between the restored record ${ }^{17}$ (Iower) and the ground motion estimated (upper) at the surface

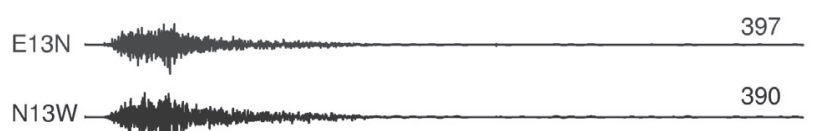

(a) Acceleration

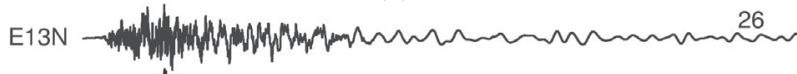

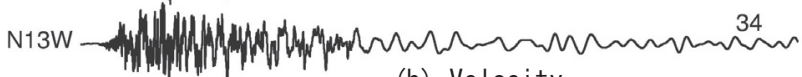

(b) Velocity

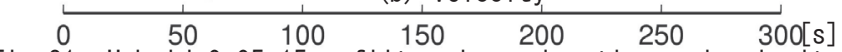

Fig. 21 Hybrid $0.05-15 \mathrm{~s}$ filtered acceleration and velocity seismograms of $\mathrm{E} 13^{\circ} \mathrm{N}$ and $\mathrm{N} 13^{\circ} \mathrm{W}$ components at the surface

分法などで計算した波形とをハイブリッドすることが望ましい。

\section{7. まとめ}

改良統計的グリーン関数法 ${ }^{10), 12)}$ により、1923 年関東地震 $(M \mathrm{~J} 7.9)$ の震度分布に合うように、強震動生成域と背景領域から成る震源モ デルと、周期 $0.05 \sim 5$ 秒の水平・上下成分の強震動の推定を行った。 推定に際しては、地盤が線形時と非線形時の計測震度の関係式 ${ }^{13)}$ を用いて、震度に対する地盤の非線形性の影響を考慮している。ま た、改良統計的グリーン関数には、表面波と散乱波の影響が考慮さ れている。以下に、得られた結果をまとめる。

a）推定された $2 つ の$ 強震動生成域の位置は、すべり量の大きい領域 18)にほぼ対応する。同じ地震モーメントに換算した短周期レベル は、地殼内地震の 1.21 倍、日本海溝のプレート境界地震の 0.74 倍、相模トラフ沿いのフィリピン海プレート内のスラブ内地震で ある 1987 年千葉県東方沖地震 $(M J 6.7)$ の 0.55 倍であった。

b) 強震観測点での推定震度分布は、諸井・武村 22$)$ にる震度 7 や 6 強の領域、その他の震度分布 ${ }^{23)}$ 27)をほぼ再現している。同じ震 源モデルで地盤の非線形性の影響を考慮しない場合には、震度 7 や 6 強の領域を過大評価する。

c）地盤が線形時の地表の推定強震動波形から、工学的基盤波を推定 し、等価線形解析コード DYNEQ40)により、地盤の非線形性を考 慮した地表の強震動波形を推定した。震度 7 相当の地点では、既 往の震度 7 相当の観測波形と同レベルの強震動波形が推定され た。一方、大手町や新宿では、2 成分のうち大きい方(NS 成分) の工学的基盤波が、告示スペクトルとほぼ同レベルであった。

d）強震観測点で得られている経験的地盤増幅率、経時特性のサイト 係数 ${ }^{10)}$ を、 $T Z^{14)}$ と $V S 30$ で回帰し、回帰式からの残差をクリギン グ手法によりモデル化して面的補間を行った。この面的補間法を 1923 年関東地震に適用し、 $250 \mathrm{~m}$ メッシュでの面的震度分布、地 盤が線形時の地表での強震動波形の推定例を示した。 e）面的に推定した波形の中から本郷での波形を選択し、今村式 2 倍 強震計の復元波である $\mathrm{E} 13^{\circ} \mathrm{N}$ 成分 ${ }^{17)}$ との比較を行った。周期 0.5 5 秒では、推定波は復元波の速度波形の最大速度、包絡形、 スペクトルレベルをほぼ再現している。復元できなかった N $13^{\circ}$ $\mathrm{W}$ 成分は、 $\mathrm{E} 13^{\circ} \mathrm{N}$ 成分より約 1.5 倍大きいことが余震記録に基 づき指摘されているが 17)、推定波形はこの特徵も再現している。

\section{謝辞}

本研究は、科学研究費補助金基盤研究(A)26242034(研究代表者川 瀬博教授) による成果である。防災科学技術研究所の K-NET ・ KiK-net の強震記録・位置・PS 検層結果と J-SHIS で公開されてい るV $V 30$ のデータ、気象庁の 95 型震度計の位置と震源情報を用いま した。また、JR 鷹取、自治体の川口町役場、東北工業大学穴澤 ・ 神山研究室のS Small-Titan の七郷小学校の記録の最大振幅值を用い ました。東京都土木技術支援・人材育成センターの「東京の地盤」 43)、千葉県の「ちば情報マップ」44)の地盤情報も使用しました。等 価線形解析では、吉田望教授のプログラム DYNEQ40)を用いました。 諸井孝文博士には、諸井・武村 22)の震度分布の図を頂きました。一 部の図の作成には GMT55)を用いました。記して感謝致します。

\section{参考文献}

1）佐藤俊明，壇一男, Graves, R.W. and Somerville, P.G.：1923 年関東大地 震 $(M s 8.2)$ の断層の一様すべり破壊を考慮した 3 次元有限差分法と半経 験的方法のハイブリッドによる東京の広帯域強震動シミュレーション, 第 10 回日本地震工学シンポジウム, Vol.1, pp.679-684, 1998.12

2）壇一男, 渡辺基史, 佐藤俊明, 宮腰淳一, 佐藤智美：統計的グリーン関数 法による 1923 年関東地震 (MJMA7.9) の広帯域強震動評価, 日本建築学会 構造系論文集，第 530 号, pp.53-62, 2000.4

3）壇一男, 渡辺基史, 佐藤俊明, 石井透：断層の非一様すべり破壊モデル から算定される短周期レベルと半経験的波形合成法による強震動予測の ための震源断層のモデル化，日本建築学会構造系論文集，第 545 号， pp.51-62, 2001.7

4) 秋山伸一, 池上泰史, アフニマル, 䋶纐一起 : 大規模 3 次元地下構造のモ デル化と強震動シミュレーション, 第 30 回地震工学研究発表会, 土木学 会地震工学論文集, 論文番号 0024,pp.1-8, 2005.9

5）松島信一, 渡辺基史, 壇一男, 佐藤俊明, 宮腰淳一：1923 年関東地震によ る首都圈での広域広带域強震動予測, 日本建築学会技術報告集, 第 26 号, pp.447-450, 2007.12

6）神田克久, 武村雅之：震度データから推察される相模トラフ沿いの巨大 地震の震源過程, 日本地震工学論文集, 第 7 巻, 第 2 号, pp.68-79, 2007.3

7）中央防災会議(事務局内閣府)首都直下地震モデル検討会：首都の M7 ク ラスの地震及び相模トラフ沿いの M8 クラスの地震等の震源断層モデル と震度分布・津波高等に関する報告書 (オンライン), 入手先 $<$ http://www.bousai.go.jp/kaigirep/chuobou/senmon/shutochokkajishin model /pdf/dansoumodel_01.pdf>, (参照 2014.3.13)

8）小山信：長周期・多数回繰り返し地震動の地域特性, BRI-H26 講習会テ キスト, (オンライン), 入手先<www.kenken.go.jp/japanese/research /lecture/h26/pdf/T6.pdf>, (参照 2015.5.11)

9）川瀬博：震源近傍地震動の地下構造による増幅プロセスと構造物破壊性 能一1995 年兵庫県南部地震での震災域の成因に学ぶー, 第 10 回日本地 震工学シンポジウムパネルディスカッション資料集, pp.29-34, 1998.12

10）佐藤智美：相模トラフ沿いの中規模地震の観測記録に基づく表面波と散 乱波を考慮した統計的グリーン関数生成方法, 日本建築学会構造系論文 集，第 705 号, pp.1589-1599, 2014.11

11) 佐藤智美：相模トラフ沿いの中規模スラブ内地震記録に基づく表面波と 散乱波を考慮した統計的グリーン関数、日本地震工学会論文集, 第 15 巻, 第 1 号, pp.116-135, 2015.2 
12) 佐藤智美：表面波と散乱波を経験的に考慮した統計的グリーン関数生成 手法に基づく 1987 年千葉県東方沖地震の強震動シミュレーション, 第 14 回日本地震工学シンポジウム, pp.1140-1149. 2014.12

13) 佐藤智美 : KiK-net 観測記録に基づく地盤の伝達関数を用いた線形時と 非線形時の計測震度の関係, 日本建築学会構造系論文集, 第 713 号, pp.1055-1065, 2015.7

14）佐藤智美，大川出，西川孝夫，佐藤俊明：長周期応答スペクトルの地盤 増幅率の経験的予測式とその理論的解釈, 日本建築学会構造系論文集, 第 669 号, pp.1905-1914, 2011.11

15）山崎文雄, 大西淳一, 田山聡, 高野辰雄 : 高速道路構造物に対する地震 被害推定式の提案，第 10 回日本地震工学シンポジウム論文集,Vol.3, pp.3491-3496, 1998.12

16）小嶋啓介，鈴木大輔：常時微動と地盤統計手法に基づく福井平野の第四 紀構造の推定, 応用地質, Vol.46, No.1, pp.9-19, 2005.4

17) 横田治彦, 片岡俊一, 田中貞二, 吉沢静代 : 1923 年関東地震のやや長周 期地震動 今村式 2 倍強震計記録による推定, 日本建築学会構造系論文報 告集, 第 401 号, pp.35-45, 1989.7

18) Sato, H., Hirata, N., Koketsu, K., Okaya, D., Abe, S., Kobayashi, R., Matsubara, M., Iwasaki, T., Ito, T., Ikawa, T., Kawanaka, T., Kasahara, K. and Harder, S. : Earthquake source fault beneath Tokyo, Science, Vol.309, pp.462-464, 2005.7

19）地震調查研究推進本部：「長周期地震動予測地図」2012 年試作版, (オン ライン), 入手先<http://www.jishin.go.jp/main/chousa/12_choshuki/>, (参照 2015.5.11)

20) 地震調査研究推進本部: 全国地震動予測地図 付録 3 震源断層を特定し た地震の強震動予測手法(「レシピ」)平成 21 年 12 月 21 日改訂(オンライ ン ), 入手先 http://www.jishin.go.jp/main/chousa/09_yosokuchizu/ g_furoku3.pdf, (参照 2014.5.26)

21) Boatwright, J. : The seismic radiation from composite models of faulting, Bull. Seism. Soc. Am., Vol.78, pp.489-508, 1988.4

22 ) 諸井孝文, 武村雅之：関東地震(1923 年 9 月 1 日)による木造住家被害デー 夕の整理と震度分布の推定, 日本地震工学会論文集, 第 2 巻, 第 3 号, pp.35-71, 2002.11

23）宇佐美達夫, 石井寿, 今村隆正, 武村雅之, 松浦律子：日本被害地震総覧 599-2012，東京大学出版会, pp.1-694, 2013.9

24) 武村雅之, 諸井孝文：地質調査所データに基づく 1923 年関東地震の詳細 震度分布 その 1 .千葉県, 日本地震工学会論文集, 第 1 巻, 第 1 号, pp.1-26, 2001.12

25) 武村雅之, 諸井孝文：地質調査所データに基づく 1923 年関東地震の詳細 震度分布 その 2 . 埼玉県, 日本地震工学会論文集, 第 2 巻, 第 2 号, pp.55-73, 2002.5

26) 武村雅之：1923年関東地震による東京都中心部(旧 15 区内)の詳細震度分 布と表層地盤構造, 日本地震工学会論文集, 第 3 巻, 第 1 号, pp.1-36, 2003.2

27) 高浜勉, 翠川三郎, 新保寛, 阿部進 : 1923 年関東地震による横浜市での 木造家屋の被害分布, 第 26 回地震工学研究発表会講演論文集, pp.105-108, 2001.8

28) Matsu'ura, M., Iwasaki, T., Suzuki, Y. and Sato, R. : Statical and dynamical study on faulting mechanism of the 1923 Kanto earthquake, J. Phys. Earth, Vol.28, pp.119-143, 1980

29) 中央防災会議 : 東南海、南海地震等に関する専門調査会（第 7 回）資料 1 (平成 14 年 12 月 24 日) (オンライン)、入手先 $<\mathrm{http}: / / \mathrm{www}$. bousai.go.jp/kaigirep/chuobou/senmon/tounankai_nankaijishin/7/pdf/ siryou1.pdf>、(参照 2014.5.26)

30) 産業技術総合研究所 活断層・地震研究センター：大阪湾周辺地域の地 震動地図一地震動予測研究成果報告一解説書一(暫定版 2005/4/11) (オン ライン)、入手先<https://unit.aist.go.jp /actfault-eq/osaka/all.pdf>、(参 照 2014.5.26)

31) 香川敬生：ハイブリッド合成法に用いる統計的グリーン関数法の長周期 带域一の拡張，日本地震工学会論文集，第 4 巻, 第 2 号, pp.21-32, 2004.5

32) Geller, R.J. : Scaling relations for earthquake source parameters and magnitudes, Bull. Seism. Soc. Am., Vol.66, pp.1501-1523, 1976.10

33) Boore, D.M. : Stochastic simulation of high-frequency ground motions based on seismological models of the radiated spectra, Bull. Seism. Soc. Am., Vol.73, pp.1865-1894,1983.12

34) 若松加寿江，松岡昌志：全国統一基準による地形・地盤分類 $250 \mathrm{~m}$ メッ シュマップの構築とその利用, 地震工学会誌, No.18, pp.35-38, 2013.1

35 ) 松岡昌志, 若松加寿江 : 地形・地盤分類 $250 \mathrm{~m}$ メッシュマップ全国版に 基づく地盤のゆれやすさデータ、産業技術総合研究所, 知的財産番号 H20PRO-936, 2008

36) Abrahamson, N. and Silva, W. : Summary of the Abrahamson \& Silva NGA ground-motion relations, Earthquake Spectra, Vol.24, No.1, pp.67-97, 2008.2

37) 佐藤智美 : 経験的グリーン関数法に基づく 2011 年東北地方太平洋沖地 震の震源モデループレート境界地震の短周期レベルに着目して一、日本 建築学会構造系論文集, 第 675 号, pp.695-704, 2012.5

38) 佐藤智美：逆断層と横ずれ断層の違いを考慮した日本の地殼内地震の短 周期レベルのスケーリング則，日本建築学会構造系論文集，第 651 号， pp.923-932, 2010.5

39) Somerville, P.G., Irikura, K., Graves, R., Sawada, S., Wald, D., Abrahamson, D., Iwasaki, Y., Kagawa, T., Smith, N. and Kowada, A. : Characterizing crustal earthquake slip models for the prediction of strong ground motion, Seismol. Res. Lett., Vol.70, pp.59-80, 1999.1

40) 吉田望：DYNEQ computer program for DYNamic response analysis of level ground by EQuivalent linear method, 東北学院大学工学部, (才 ンライン), 入手先<http://boh0709.ld.infoseek.co.jp/>, (参照 2015.6.12)

41) Kawase, H., Sánchez-Sesma F.J. and Matsushima S. : The optimal use of horizontal-to-vertical (H/V) spectral ratios of earthquake motions for velocity structure inversions based on diffuse field theory for plane waves, Bull. Seism. Soc. Am., Vol.101,pp.2001-2014, 2011.10

42) Satoh, T., Hayakawa, T., Oshima, M., Kawase, H., Matsushima, S., Nagashima, F. and Tobita, K. : Site effects on large ground motions at a KiK-net Iwase station (IBRH11) during the 2011 Tohoku earthquake, Bull. Seism. Am., Vol.104, pp.653-668, 2014.4

43）東京都土木技術支援・人材育成センター：東京の地盤(オンライン), 入手 先<http://doboku.metro.tokyo.jp/>, (参照 2015.6.9)

44) 千葉県：ちば情報マップ(オンライン), 入手先<http://map.pref. chiba.lg.jp/map.asp?dtp=6300\&mpx=140\%2E12628598096452\&mpy= $35 \% 2 \mathrm{E} 60133767835524 \& \mathrm{mps}=10000 \& \mathrm{bdtp}=6300>$, (参照 2015.6 .9$)$

45) 狐崎長琅, 後藤典俊, 小林芳正, 井川猛, 堀家正則, 斉藤徳美, 黒田徹, 山 根一修, 奥住宏一：地震動予測のための深層地盤 $\mathrm{P} \cdot \mathrm{S}$ 波速度の推定の自 然災害科学, Vol.9-3, pp.1-17, 1990.12

46) Gardner, G.H.F., Gardner, L.W. and Gregory, A.R. : Formation velocity and density - the diagnostic basics for stratigraphic traps, Geophysics, Vol. 29, pp.770-780, 1974

47) Kinoshita, S. : Deep-borehole-measured $Q_{P}$ and $Q_{S}$ attenuation for two Kanto sediment layer sites, Bull. Seism. Soc. Am., Vol.98, pp.463-468, 2008.2

48) 安田進, 山口勇：種々の不攪乱土における動的変形特性, 第 20 回土質工 学研究発表会講演集, pp.539-542, 1985.5

49) 福元俊一, 吉田望, 佐原守 : 堆積軟岩の動的変形特性, 日本地震工学会 論文集，第 9 巻，第 1 号, pp.46-64, 2009.2

50) 内田明彦，時松孝次：大ひずみ領域における不覚乱砂質・礫質土の変形 特性, 日本建築学会構造系論文集, 第 561 号, pp.103-109, 2002.11

51) 吉田望：地盤の地震応答解析, 鹿島出版会, pp.1-266, 2011.12

52) 川瀬博, 松尾秀典：K-NET, KiK-net, JMA 震度計観測網による強震記録 から分離したサイト増幅特性と $\mathrm{S}$ 波速度構造との対応, 日本地震工学会 論文，第 4 巻，第 4 号, 126-145, 2004.9

53) 岩田孝行, 野口和子：東京大学における地震観測及び機械式地震計の名 称と分類について, 東京大学地震研究所技術報告, No.6, pp.78-94, 2000

54) 鈴木幹夫, 斉藤賢二, 石井透, 佐藤俊明 : 東京大学 (地震) 総合研究棟, 日 本免震構造協会季刊誌 MENSHIN, 49 号, 2005.8

55) Wessel, P. and Smith, W.H.F. : New, improved version of Generic Mapping Tools released, EOS, AGU, 1998 


\title{
ESTIMATION OF STRONG MOTION GENERATION AREAS AND STRONG MOTIONS DURING THE 1923 KANTO EARTHQUAKE USING REVISED STOCHASTIC GREEN'S FUNCTION METHOD
}

\author{
Toshimi SATOH* \\ * Institute of Technology, Shimizu Corporation, Chief Researcher, Dr.Eng.
}

We estimate strong motion generation areas (SMGAs) and three-component strong motions in the period range 0.05 to $5 \mathrm{~s}$ during the 1923 Kanto earthquake $\left(M_{\mathrm{J}} 7.9\right)$ by the forward modeling of the seismic intensity scale using the revised stochastic Green's function method. Surface and scattering waves as well as S-waves are empirically considered in the revised stochastic Green's function method. In addition the nonlinear site effects on the seismic intensity scale are considered by an empirical relation between the seismic intensity scale affected by linear and nonlinear site responses.

Two SMGAs are located at almost the same position as large slip areas resolved by the kinematic waveform inversions (Sato et al., 2005) using the low-frequency strong motion records. The stress drops of the SMGAs are 14.5 and 21.8 MPa, which are smaller than $25 \mathrm{MPa}$ used by Central Disaster Prevention Council for seismic intensity scale estimation using the previous stochastic Green's function method. The estimated short-period spectral level of the acceleration source spectrum is 1.21 times of crustal earthquakes and 0.74 times of interplate earthquakes along the Japan Trench and 0.55 times of the 1987 Chiba-ken-toho-oki earthquake along the Sagami Trough. The estimated strong motions reproduce the seismic intensity scale estimated by Japan Meteorological Agency, Moroi and Takemura (2002) and others. In the case without consideration of nonlinear site effects, strong motions overestimate the seismic intensity scale in the near fault region.

Strong motions at the engineering bedrock at nine stations are estimated from the strong motions estimated at the surface in the linear regime using the theoretical linear site amplification factors. The strong motions at the surface are estimated using the revised equivalent linear analysis code DYNEQ by Yoshida. Estimated strong motions with seismic intensity scale of 7 are comparable to several records with seismic intensity scale of 7 for the other earthquakes. Strong motions at Odawara are the largest since the amplification factor in the period range 0.5 to $2 \mathrm{~s}$ is largest among all strong motion stations in the Kanto region and one SMGA is located at a depth of $7 \mathrm{~km}$ just beneath Odawara. In the Tokyo metropolitan area the peak ground accelerations are 400 to $550 \mathrm{~cm} / \mathrm{s}^{2}$ and the peak ground velocities at the surface are about 60 and $30 \mathrm{~cm} / \mathrm{s}$ for north-south and east-west components, respectively. The spectra of north-south component at the engineering bedrock there are consistent with the building standard law notification spectrum for the level-2 ground motion.

Site amplification factors of spectral model and site coefficients of envelope model for both S-wave and later phase windows are interpolated by applying the Kriging method to the residual of the empirical relation modeled by $\mathrm{Tz}$ (one fourth of predominant period from the seismic bedrock to the engineering bedrock) and Vs30. Using this interpolation method we estimate strong motions with $250 \mathrm{~m}$ spatial resolution in a $10 \mathrm{~km} \times 10 \mathrm{~km}$ area including Hongo. The strong motion of $\mathrm{E} 13^{\circ} \mathrm{N}$ component estimated at Hongo is consistent with the record restored by Yokota et al.(1989) from an Imamura type seismogram in the period range 0.5 to $5 \mathrm{~s}$. The $\mathrm{N} 13^{\circ} \mathrm{W}$ component could not be restored because main parts of the record had been totally saturated. The $\mathrm{N} 13^{\circ} \mathrm{W}$ components of the Imamura type seismograms of seven aftershocks were estimated to be about 1.5 times larger than E13 ${ }^{\circ} \mathrm{N}$ components by Yokota et al.(1989). The strong motion of the $\mathrm{N} 13^{\circ} \mathrm{W}$ component estimated in this study is also 1.5 times larger than $\mathrm{E} 13^{\circ} \mathrm{N}$ component. 